\title{
Intrasellar herniation
}

\section{A newly described variant of downward central herniation}

Felipe T. Pacheco, MD, PhD, Kambiz Nael, MD, and Puneet S. Pawha, MD

Neurology ${ }^{\circledR}$ 2018;91:889-890. doi:10.1212/WNL.0000000000006470

\section{Correspondence}

Dr. Pacheco

felipetorrespacheco@

hotmail.com

Figure 1 Downward central herniation of basal frontal gyri into the sella
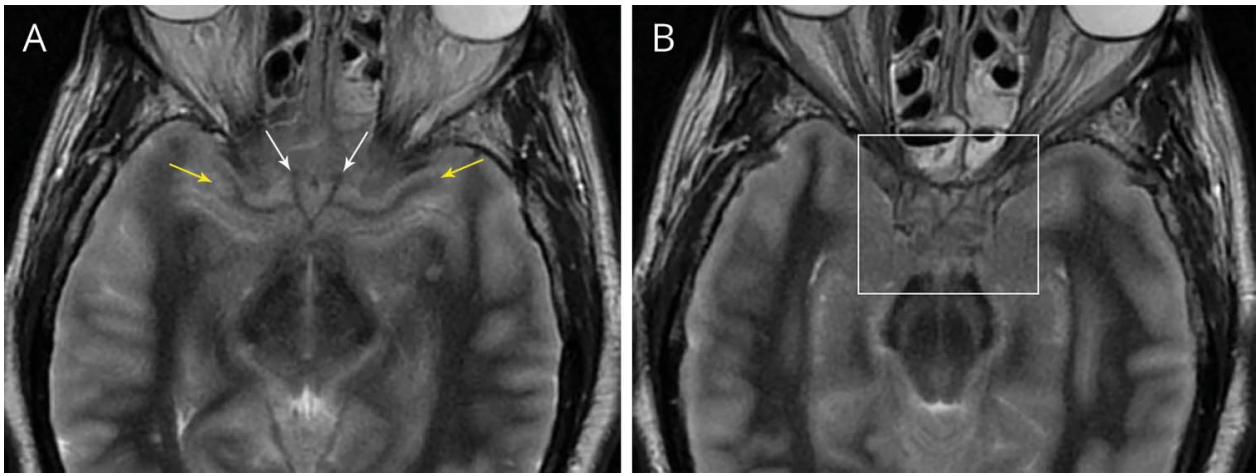

(A) Axial T2-weighted image shows gyri recti (white arrows) and posterior orbital gyri (yellow arrows) extended inferiorly and centrally towards the sella. (B) A puckered appearance of the herniated gyri is seen within the sella. Elsewhere in the brain, diffuse cortical T2 hyperintensity and swelling reflects cerebral edema.

A 72-year-old woman was brought to the emergency department in cardiac arrest. Return of spontaneous circulation was reestablished. She was subsequently comatose with absent brainstem reflexes. In the setting of diffuse hypoxic injury, MRI revealed diffuse cerebral edema and absent cerebral perfusion, suggesting brain death. Due to substantially increased intracranial pressure, there was downward central intrasellar herniation of the gyri recti, posterior orbital gyri, septal area, anterior third ventricle, anterior hypothalamus, and optic chiasm (figures 1 and 2). Several types of acquired herniation are well known and extensively discussed in the literature. ${ }^{1,2}$ Intrasellar downward cerebral herniation has not previously been described.

\section{Author contributions}

Dr. Pacheco: study concept and design. Dr. Nael: analysis and interpretation. Dr. Pawha: critical revision of the manuscript for important intellectual content and study supervision.

\section{Study funding}

No targeted funding reported.

\section{Disclosure}

The authors report no disclosures relevant to the manuscript. Go to Neurology.org/ $\mathrm{N}$ for full disclosures.

\section{References}

1. Laine FJ, Shedden AI, Dunn MM, Ghatak NR. Acquired intracranial herniations: MR imaging findings. AJR Am J Roentgenol 1995; 165: 967-973.

2. Johnson PL, Eckard DA, Chason DP, Brecheisen MA, Batnitzky S. Imaging of acquired cerebral herniations. Neuroimaging Clin N Am 2002;12:217-228.

From the Division of Neuroradiology (F.T.P.), Santa Casa de São Paulo School of Medical Sciences and Diagnósticos da América-DASA, Brazil; and Departments of Neuroradiology and Radiology (K.N., P.S.P.), Icahn School of Medicine at Mount Sinai, New York, NY.

Go to Neurology.org/N for full disclosures. Funding information and disclosures deemed relevant by the authors, if any, are provided at the end of the article. 
Figure 2 Diffuse cerebral edema and increased intracranial pressure causing intrasellar herniation
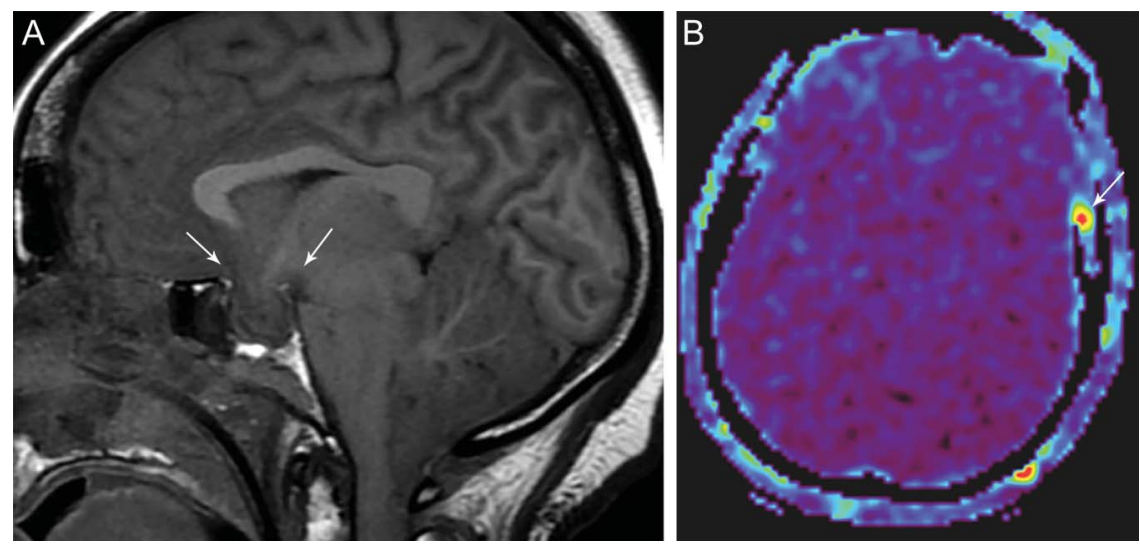

(A) Sagittal T1-weighted image demonstrates downward herniation of the central suprasellar structures (arrows). Other signs of increased intracranial pressure seen, including CSF effacement and tonsillar herniation. (B) Cerebral blood flow from arterial spin labeling (ASL) MR perfusion shows absent cerebral perfusion, with preserved external carotid branches (arrow), suggesting brain death.

\section{Disputes \& Debates: Rapid online correspondence}

The editors encourage comments on recent articles through Disputes \& Debates:

Access an article at Neurology.org/ $\mathrm{N}$ and click on "COMMENT" beneath the article header. Responses will be posted within 3 business days.

Before submitting a comment to Disputes \& Debates, remember the following:

- Disputes \& Debates is restricted to comments about studies published in Neurology within the last eight weeks

- Read previously posted comments; redundant comments will not be posted

- Your submission must be 200 words or less and have a maximum of five references; reference one must be the article on which you are commenting

- You can include a maximum of five authors (including yourself)

\section{Visit the Neurology ${ }^{\circledR}$ Website at Neurology.org/N}

- More article-based content on home pages

- Streamlined menus and navigation

- Enhanced blog sections for specialty areas

- $\quad$ Same experience on desktop, tablet, and mobile devices

- Audio summaries of current issues

- Improved article reading experience; links more evident (pdf, analytics, social media)

- Neurology ${ }^{\circledR}$ Clinical Practice initiative "Practice Current" global surveys will be accessible across sites

f Find Neurology ${ }^{\circledR}$ on Facebook: http://tinyurl.com/neurologyfan

Follow Neurology ${ }^{\circledR}$ on Twitter: https://twitter.com/GreenJournal 


\section{Neurology}

\section{Intrasellar herniation: A newly described variant of downward central herniation}

Felipe T. Pacheco, Kambiz Nael and Puneet S. Pawha

Neurology 2018;91;889-890

DOI 10.1212/WNL.0000000000006470

This information is current as of November 5, 2018

\section{Updated Information \&} Services

References

Subspecialty Collections

Permissions \& Licensing

Reprints including high resolution figures, can be found at: http://n.neurology.org/content/91/19/889.full

This article cites 2 articles, 0 of which you can access for free at: http://n.neurology.org/content/91/19/889.full\#ref-list-1

This article, along with others on similar topics, appears in the following collection(s):

\section{Coma}

http://n.neurology.org/cgi/collection/coma

Critical care

http://n.neurology.org/cgi/collection/critical_care

MRI

http://n.neurology.org/cgi/collection/mri

Prognosis

http://n.neurology.org/cgi/collection/prognosis

Information about reproducing this article in parts (figures,tables) or in its entirety can be found online at:

http://www.neurology.org/about/about_the_journal\#permissions

Information about ordering reprints can be found online:

http://n.neurology.org/subscribers/advertise

Neurology ${ }^{\circledR}$ is the official journal of the American Academy of Neurology. Published continuously since 1951, it is now a weekly with 48 issues per year. Copyright () 2018 American Academy of Neurology. All rights reserved. Print ISSN: 0028-3878. Online ISSN: 1526-632X.

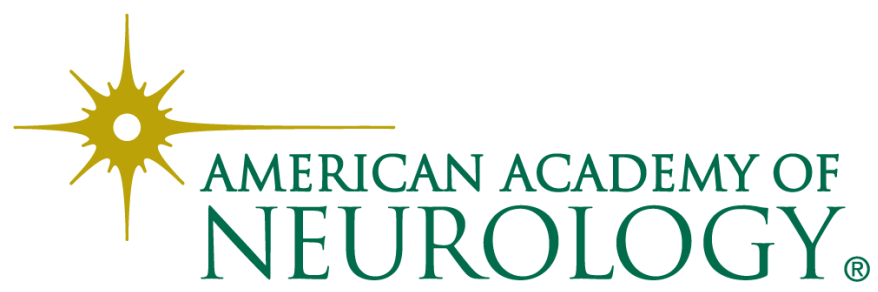

